\title{
Effect of the use of 'Meju' added with roasted rice on the quality of 'Ganjang'
}

\author{
Sung Ran Yoon ${ }^{1 *}$, Jung A Ryu ${ }^{1}$, Kil Su Jang ${ }^{1}$, Namhyeok Chung ${ }^{2}$, Jung Gi Ryu ${ }^{1}$ \\ ${ }^{I}$ Division of Agriculture Environment Research, Gyongsangbuk-do Agricultural Research and Extension Services, \\ Daegu 41404, Korea \\ ${ }^{2}$ Center of Food and Drug Analysis, Busan Regional Office of Food and Drug Safety, Busan 47537, Korea
}

\section{볶음쌀을 첨가한 메주 사용이 간장의 품질에 미치는 영향}

\author{
윤성란 $^{1 *} \cdot$ 류정아 ${ }^{1} \cdot$ 장길수 $^{1} \cdot$ 정남혁 $^{2} \cdot$ 류정기 $^{1}$ \\ 1경상북도농업기술원 농업환경연구과, ${ }^{2}$ 부산지방식품의약품안전청
}

\begin{abstract}
This study examined the quality characteristics of 'Ganjang' prepared with 'Meju' containing roasted rice additives $(0 \%, 10 \%, 30 \%, 50 \%)$ for improving the flavor of traditional 'Ganjang'. The differences between the flavor-enhanced 'Ganjang' and their traditional counterparts were also analyzed. The total nitrogen and amino acid nitrogen contents of the 'Ganjang' prepared using 'Meju' containing roasted rice additives decreased with increasing amount of roasted rice additives. Reducing sugar content was the highest in 'Ganjang' in which $\mathbf{3 0 \%}$ roasted rice was added to 'Meju' Analysis of the free amino acids in 'Ganjang' showed that contents of the amino acids with a bitter tastes during 'Ganjang' production decreased upon the addition of roasted rice; among the amino acids with a sweet taste, threonine content was high, and the glutamic acid content with a savory taste was similar. Additionally, E-nose and E-tongue analyses showed that there were differences between 'Ganjang' prepared using 'Meju' with roasted rice additives and the existing 'Ganjang'. E-nose analysis suggested that such differences originated due to the fruity odors of ethyl acetate and tert-butyl acetate and the roasting odor of pyrazine in 'Ganjang' with roasted rice additives. E-tongue analysis exhibited high SWS sensor values, which responds to sweetness. Therefore, this study confirmed the use of roasted rice for taste improvement, which increased the sweet tastes and, fruity and roasting odors during the production of traditional 'Ganjang'.
\end{abstract}

Key words : 'Gangjang', roasted rice, 'Meju', E-nose, E-tongue

서 론

간장은 콩을 주원료로 만든 발효식품으로 과거 필수 아미 노산과 지방산의 공급원이 되어왔으며, 조미료로서 한국인의 식생활에서 중요한 부분을 차지해 왔다(Choi 등, 2006). 간장 의 주성분은 아미노산, 당류, 발효에 의해 생성된 알코올과 유기산, 소금 등으로 구수한 맛과 단맛 및 고유의 향미와 짠
맛이 조화된 천연조미료이며(Yang 등, 2019), 최근 간장에 함 유된 methionine은 알코올과 니코틴의 해독작용(Shin과 Jeong, 2015), 레시틴은 콜레스테롤 용해로 동맥경화 예방과 혈압강 하 작용이 있는 것으로 보고되고 있다(Choi 등 1998; Lee와 Cho, 1971; Okamoto 등, 1995). 그러나 한식간장은 특유의 쿰쿰한 냄새가 심한 경우가 있어 신세대나 외국인 등 다양한 소비층의 확대가 어렵다는 점이 지적된다(Chang과 Chang,

*Corresponding author. E-mail : sryoon@korea.kr, Phone : +82-53-320-0453, Fax : +82-53-320-0295

Received 19 October 2020; Revised 31 October 2020; Accepted 02 November 2020.

Copyright (c) The Korean Society of Food Preservation.

This is an Open Access article distributed under the terms of the Creative Commons Attribution Non-Commercial License (http://creativecommons.org/licenses/by-nc/4.0) which permits unrestricted non-commercial use, distribution, and reproduction in any medium, provided the original work is properly cited. 
2007). 이에 한식간장의 소비층 확대를 위해서는 맛과 풍미 의 개선이 필요하다.

일본은 간장의 맛에 대해서 특히 감칠맛인 글루탐산 생성 증가 방법, 젖산의 생성에 관여하는 미생물 및 그와 관련한 효소 수준까지 깊이 연구되어져 있다(Kim, 2007). Kaneko 등 (1994)은 콩만을 사용한 한국 전통간장과 달리 콩과 밀을 1:1비율로 섞어 만든 Koji로 장을 담금으로 glutamic acid, 유 기산 함량, 유리당, 총질소 함량이 한국 전통간장에 비해 높 고, 맛과 향이 풍부한 것으로 보고하였다. 반면에 한식간장의 품질개선과 관련한 연구를 살펴보면, 보리 등겨를 첨가해 제 조한 간장에서 유리당 함량이 높게 나타났으며, 특히 포도당 이 대조구에 비해 약 10 배나 높게 검출되어 간장의 감미에 중요한 역할을 한다고 보고하였다(Choi와 Park, 2004; Lee 등, 2002). 또한, Jeong 등(2014)의 연구에서는 간장 제조 시 콩알메주와 미강을 9:1로 제조하였을 때 총질소, 아미노산성 질소, 총 유리아미노산 함량 및 기호도가 우수한 것으로 보고 하였다. 사용되는 염수로 고로쇠와 대나무 수액으로 담근 간장 에서는 무기질, 유리당 및 아미노산의 함량이 높아 영양학적 및 기능적 측면에서 우수하다고 보고하였다(Chung 등, 2001). $\mathrm{Yu}$ 등(1972)과 Lee 등(1974)은 개량식 간장의 원료 중 탈지 대두 대체제로 옥수수 글루텐과 소맥 글루텐 사용을 보고하 였다.

재래식 콩 발효식품은 초기에 콩을 원료로 하여 제조한 메 주가 주를 이루었으나, 조선 명종조(明宗朝)에 이르러 콩과 콩 이외의 전분질을 이용한 메주가 제조되었으며, 이때 사용 된 전분질원으로 쌀을 사용한 보고가 있다(Jung 등, 1994). 장류 제조에 쌀을 이용한 연구는 Lee 등(2012)의 쌀 메주 형 태 및 starter 첨가에 따른 쌀된장 품질특성 연구, 쌀된장 제조 시 전처리 및 숙성온도에 관한 연구(Jung 등, 1995) 등이 있 으나, 대부분 된장 연구에 국한되어져 있으며, 간장에 관한 연구는 미흡하다. Shi 등(2018)은 쌀을 볶음처리 함에 따라 쌀 표면의 균열과 전분 결정구조가 파괴되는 구조적인 변화 와 더불어 furans 및 pyrazines의 화합물 함량이 증가한다고 보고하였다. 따라서 본 연구에서는 기존의 전통적인 한식간 장의 풍미 개선을 위해 볶음쌀을 첨가한 메주를 사용하여 제 조한 간장의 품질특성을 조사하고, 기존의 한식간장과의 차 별성을 분석하고자 하였다.

\section{재료 및 방법}

\section{실험재료}

실험에 사용된 대두는 경북 고령지역에서 생산된 대원콩 (Daewon bean)과 경북 영주지역에서 생산된 부석태(Buseoktae bean) 품종을 사용하였으며, 쌀은 백미로 일품벼(Ilpumbyeo)
품종을 사용하였다. 메주 제조 시 쌀은 세척 후 $180^{\circ} \mathrm{C}$ 에서 20 분간 볶음(Roaster $1 \mathrm{~K}$, Taewan automation Co., Bucheon, Korea) 처리하여 사용하였다.

\section{메주 제조}

메주의 제조는 콩을 세척하여 약 5시간 물에 불린 후 증자 (40-50분, $\left.1.5 \mathrm{~kg} / \mathrm{cm}^{2}\right)$ 하여 파쇄한 후 볶음 처리한 쌀을 0 , $10,30,50 \%$ 첨가하여 사각메주로 성형하였다. 성형된 메주 는 발효실에서 약 28 일 발효하였으며, 메주 1 개당 무게는 1.2 $\mathrm{kg}$ 정도였다.

\section{장 담금 및 간장 제조}

간장 제조에 사용된 소금물은 $17 \%$ 농도로 사용하였으며, 메주와 소금물의 비율은 $1: 4(\mathrm{w} / \mathrm{v})$ 로 하였다. 60 일 동안 담금 한 후 간장과 된장을 분리하였다. 분리된 간장은 항아리에 담 아 햇빛이 잘 드는 장소에서 150 일 동안 보관한 후 분석시료 로 사용하였다.

\section{환원당 측정}

환원당 측정은 3,5-dinitrosalicylic acid(DNS)법(Miller, 1959) 에 따라 측정하였다. 즉, 시료를 일정량으로 희석한 후 시료 $2 \mathrm{~mL}$ 와 DNS 시약 $2 \mathrm{~mL}$ 를 가하여 끓는 물에 5 분 중탕한 후 충분히 냉각하여 $540 \mathrm{~nm}$ 에서 흡광도(Optizen 2120UV, Mecasys Co., Daejeon, Korea)를 측정하였다. Glucose(Sigma Chemical Co., St. Louis, MO, USA)를 표준물질로 하여 작 성한 검량곡선으로 환원당 함량(\%)을 계산하였다.

\section{아미노산성 질소 측정}

시료액 $5 \mathrm{~mL}$ 에 중성 포르말린 용액(pH 8.3) $10 \mathrm{~mL}$ 와 증 류수 $10 \mathrm{~mL}$ 를 넣어 $0.1 \mathrm{~N} \mathrm{NaOH}$ 용액으로 $\mathrm{pH} 8.4$ 가 되도록 적정하였다. 이때 소모된 $0.1 \mathrm{~N} \mathrm{NaOH} \mathrm{mL}$ 수를 아미노산성 질소 함량으로 환산하였다. 대조구는 중성 포르말린을 대신 하여 증류수를 사용하여 측정하였다.

\section{총질소 측정}

Digestion system(HP630, Mtops, yangju, Korea)으로 시 료 약 $3 \mathrm{~mL}$ 를 취하여 진한 $\mathrm{H}_{2} \mathrm{SO}_{4} 20 \mathrm{~mL}$ 를 첨가하여 분해시 키고, Kjeltec system(8200 Distilling Unit, Foss, Höganäs, Sweden)을 사용하여 증류한 후 적정하여 소비된 $0.1 \mathrm{~N} \mathrm{HCl}$ 의 $\mathrm{mL}$ 수를 총질소로 환산하여 양을 구하였다.

\section{유리아미노산 분석}

유리아미노산 분석을 위해 간장 $1 \mathrm{~mL}$ 를 탈염한 후 membrane filter로 여과한 후 $10 \mu \mathrm{L}$ 취하여 borate buffer 70 
$\mu \mathrm{L}$ 와 혼합시키고, 여기에 $\mathrm{AccQ}$ 유도체 용액 $20 \mu \mathrm{L}$ 를 첨가하 여 1 분간 정치 후 $55^{\circ} \mathrm{C}$ 에서 10 분간 반응하였다. 분석기기는 UHPLC(Thermo Ultimate 3000 Dionex, Thermo Scientific, Germering, Germany)를 사용하였으며, 컬럼은 $\mathrm{C} 18(1.7 \mu \mathrm{m}$, $2.1 \times 150 \mathrm{~nm}$, Waters, Ireland)를 사용하였고, Diode Arrary 검출기(UV $260 \mathrm{~nm}$ )로 검출하였다. 이동상은 $20 \% \mathrm{AccQ}$ Tag Eluent A(이동상 A)와 $100 \%$ acetonitrile(이동상 B)의 비 율을 99.9:0.1(1.54분) $\rightarrow 90.9: 9.1(15.22$ 분) $\rightarrow 78.8: 21.2$ (20.47분) $\rightarrow 40.4: 59.6$ (21.26분) $\rightarrow 10: 90(22.84$ 분 $) \rightarrow 99.9: 0.1(26$ 분 $) \rightarrow$ 99.9:0.1(40분)으로 유속은 $1 \mathrm{~mL} / \mathrm{min}$ 의 조건으로 분석하였다.

\section{전자코를 이용한 휘발성분 패턴 분석}

휘발성분 분석을 위해 시료 $1 \mathrm{~mL}$ 를 headspace vial(22.5× $75 \mathrm{~mm}, \mathrm{PTFE} /$ silicon septum, aluminum cap)에 넣고 $40^{\circ} \mathrm{C}$ 에 서 $500 \mathrm{rpm}$ 으로 5 분간 교반하면서 headspace를 포집하였다. 자동시료채취기를 사용하여 $1,000 \mu \mathrm{L}$ 의 휘발성분을 취한 후 전자코(Heracles, Alpha MOS, Toulouse, France)로 주입하였 고, 두 개의 column $(2 \mathrm{~m} \times 0.18 \mathrm{~mm}$ DB5/DB1701) 및 두 개의 flame ionization detectors(FID)로 분석하였다. Oven 온도는 $40^{\circ} \mathrm{C}$ 에서 5 초간 유지되었고, $270^{\circ} \mathrm{C}$ 까지 초당 $4^{\circ} \mathrm{C}$ 로 상승시켜 30 초간 유지되었으며, 수소가스의 flow rate는 $1 \mathrm{~mL} / \mathrm{min}$ 였 다. Kovats index library 기반의 AroChembase(Alpha MOS) 를 이용하여 분리된 피크의 성분을 추정하였고, 3 회 반복 결 과를 주성분(principal component analysis, PCA) 분석에 사 용하였다.

\section{전자혀를 이용한 맛 패턴 분석}

간장 시료의 맛은 7개의 electrochemical sensor(SRS, $\mathrm{GPS}$, STS, UMS, SPS, SWS, BRS)와 1개의 reference electrode $(\mathrm{Ag} / \mathrm{AgCl})$ 가 부착된 전자혀(Astree, Alpha MOS, Toulouse, France)를 이용하여 분석하였다. 이때 SRS는 신맛, $\mathrm{STS}$ 는 짠맛, $\mathrm{UMS}$ 는 감칠맛, $\mathrm{SWS}$ 는 단맛, $\mathrm{BRS}$ 는 쓴맛을 감 지하고, GPS와 SPS는 센서값을 보정하는 표준센서로 사용 된다. 각 시료 $5 \mathrm{~mL}$ 를 120 초 동안 분석하였고, 시료간 오염 을 방지하기 위해 증류수로 세척하였으며, 5 회 분석결과를 주성분 분석(PCA)에 사용하였다.

\section{통계처리}

모든 데이터는 3 회 반복 측정하였으며, mean $\pm \mathrm{SD}$ 로 표현하 였다. 또한, 얻어진 결과를 통계프로그램(Statistical Analysis System; version 9.2, SAS Institute, Cary, NC, USA)을 이용 하여 각각의 변수에 대한 특성을 분석하였으며, 각 시험구간 의 평균차이에 대한 유의성 검정은 Duncan's multiple range test를 이용하여 $p<0.05$ 수준일 때 유의한 차이가 있는 것으
로 간주하였다.

\section{결과 및 고찰}

\section{볶음쌀 첨가 메주의 품질특성}

메주 제조시 볶음쌀 첨가 비율을 $0,10,30,50 \%$ 로 달리하 여 제조한 메주의 품질분석으로 환원당 및 아미노산성 질소 함량을 분석한 결과는 Fig. 1 및 2와 같다. 환원당 함량은 볶 음쌀 첨가량이 증가할수록 $0.57 \%$ 에서 $2.04 \%$ 까지 증가하는 것으로 나타났다. 볶음쌀을 첨가함으로써 수용성 당질 함량 과 조직구조의 변화에 의해 당 함량이 증가된 것으로 판단된 다(Lee 등, 2004). 환원당은 메주에서 전분분해효소의 작용 으로 증가하다가 된장 내 미생물의 영양원, 유기산 발효의 기 질로 이용되어지는 것으로 알려져 있다(Yoo 등, 2000). 볶음 쌀 메주 환원당은 간장제조시 미생물의 영양원으로 사용되어

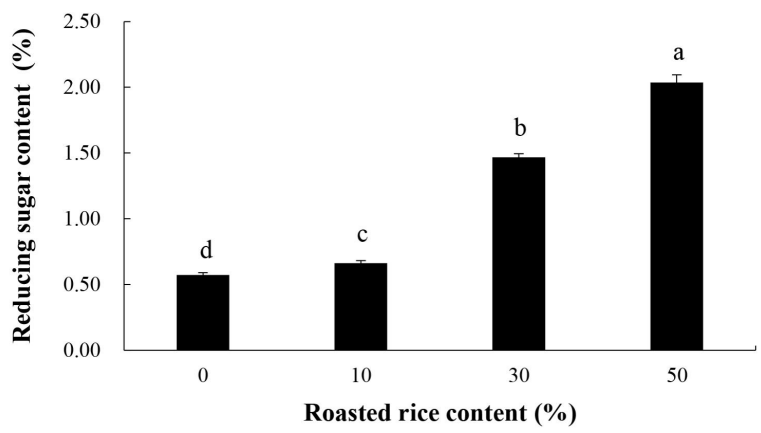

Fig. 1. Reducing sugar content of 'Meju' added with roasted rice. Values represent the mean \pm SD $(n=3)$. Means with different letters $\left({ }^{a-d}\right)$ above a bar are significantly different at $\mathrm{p}<0.05$.

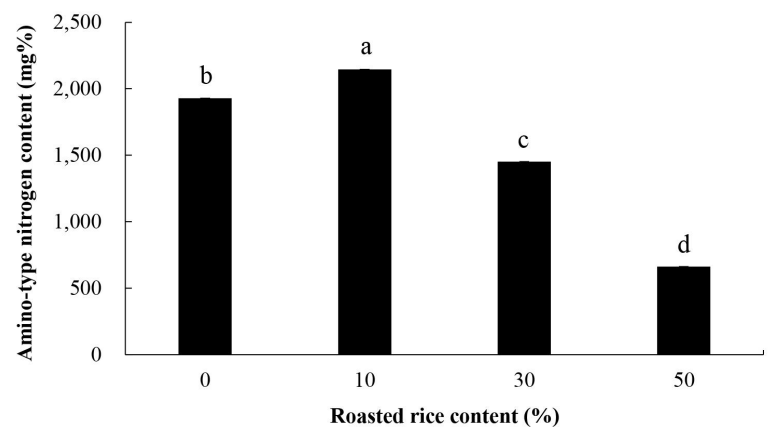

Fig. 2. Amino-type nitrogen content of 'Meju' added with roasted rice.

Values represent the mean \pm SD $(n=3)$. Means with different letters $\left({ }^{a-d}\right)$ above a bar are significantly different at $\mathrm{p}<0.05$. 
질 것으로 기대된다. Park 등(2001)은 쌀 첨가량이 증가할수 록 전분을 분해하는 $\alpha$-amylase 활성이 증가하는 것으로 보고 하였다. 아미노산성 질소는 발효식품속의 원료 단백질이 아 미노산으로 분해되는 정도를 판단하는 기준이며, 또한 된장 제조 및 숙성 과정 중 단백질이 효소작용으로 가수분해되어 맛을 내는 아미노산으로 변화된다고 알려져 있다(Rho 등, 2008). 아미노산성 질소 함량은 볶음쌀 $10 \%$ 첨가한 메주에 서 $2,146 \mathrm{mg} \%$ 로 가장 높았으나, 그 이상 첨가 시에는 감소하 는 것으로 나타났다. Park 등(2001)은 쌀 분말 첨가 $10 \%$ 에서 protease 활성이 가장 높다고 보고하였으며, 또한 쌀 분말의 첨가로 인해 콩 표면의 수분이 흡수됨으로써 첨가량이 증가 하면 효소활성이 감소된다고 하였는데, 본 연구의 결과에서 도 볶음쌀 $50 \%$ 첨가 시에는 아미노산성 질소 함량이 급격하 게 감소되어짐을 볼 수 있었다.

\section{볶음쌀 첨가 메주로 담근 간장의 환원당 함량}

간장의 숙성기간 중 미생물이 전분질을 가수분해하여 생 성되는 당은 장류의 맛 성분이다. 볶음쌀 첨가 메주로 담근 간장의 환원당 함량을 비교한 결과는 Fig. 3 과 같다. 사용한 메주의 볶음쌀 첨가량이 증가할수록 환원당 함량이 증가하다 가 볶음쌀을 $30 \%$ 첨가한 메주를 사용한 간장에서 가장 높은 $1.16 \%$ 로 나타났으며, $50 \%$ 첨가한 메주를 사용한 간장에서 는 감소하는 것으로 나타났다. Jeon 등(2002)은 간장 내의 환 원당은 간장의 사입과 숙성 중 유입된 미생물에 의해 생성된 amylase가 메주 중의 전분질을 분해하여 생성되므로 amylase의 활성과 연관 지을 수 있으며, 젖산발효나 알코올 발효의 기질로도 이용되는 양이 많을 것이므로 숙성기간 환 원당의 증감에 영향을 미치는 것으로 보고하였다. 본 연구에 서 간장의 환원당 함량은 미생물에 의해 전분이 가수분해된 후 젖산발효나 알코올발효의 기질로 사용하고 남은 함량으로

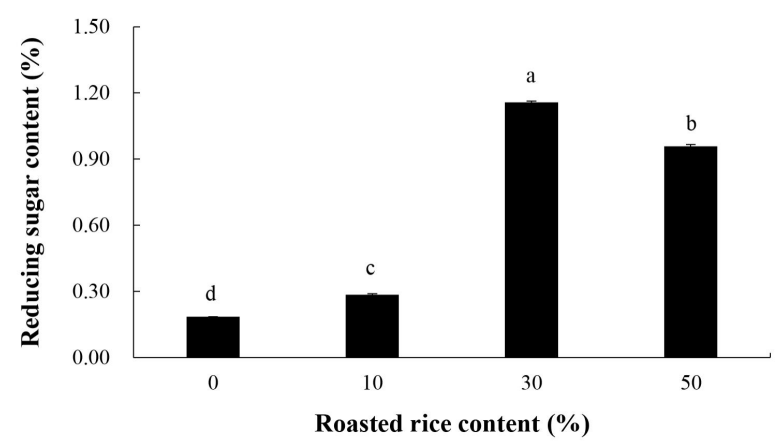

Fig. 3. Reducing sugar content of 'Ganjang' prepared from 'Meju' added with roasted rice.

Values represent the mean $\pm S D(n=3)$. Means with different letters $\left(^{a-d}\right)$ above a bar are significantly different at $\mathrm{p}<0.05$.
추측된다. 또한, 간장의 단맛 성분인 당 함량은 볶음쌀을 $30 \%$ 첨가한 간장이 무처리보다 6 배 정도 높으므로 볶음쌀 첨가에 따른 간장의 단맛 상승효과가 있는 것으로 판단되었다.

\section{볶음쌀 첨가 메주로 담근 간장의 총질소 및 아미노산성 질소 함량 비교}

볶음쌀 첨가 메주로 담근 간장의 총질소 및 아미노산성 질 소 함량을 비교한 결과는 Table 1 과 같다. 간장의 총질소 함 량은 볶음쌀 첨가량이 증가할수록 감소되어지는 것으로 나타 났다. 일반적으로 한식 간장의 총질소 함량의 품질기준은 $0.7 \%$ 이며(MFDS, 2017), 볶음쌀 $30 \%$ 첨가까지는 품질기준 에 적합하게 나타남을 볼 수 있었다. 볶음쌀의 첨가량을 달리 한 메주를 사용한 간장의 아미노산성 질소 함량은 무처리구 에서 $836.64 \mathrm{mg} \%$ 로 나타났으며, 볶음쌀을 $50 \%$ 첨가한 메주 를 사용한 간장은 $425.09 \mathrm{mg} \%$ 로 낮게 나타났다. Jeong 등 (2014)은 간장 제조 시 미강첨가 비율이 높을수록 아미노산 성 질소 함량이 낮다고 보고하였다. 또한, Sun 등(1987)은 탈 지대두와 밀가루 코오지 첨가비율을 달리하여 간장을 제조하 였을 때 밀가루 코오지 첨가량이 높을수록 아미노산성 질소 함량이 낮다고 보고하였다. Kyoun 등(2006)은 쌀 품종별 영 양성분에서 단백질 함량을 평균 $6.07 \%$ 로 보고하였으며, Im 등(2016)은 콩 종류에 따른 단백질 함량을 평균 $41.5 \%$ 로 보 고하였다. Choi와 Rhee(1994)는 콩 된장이 쌀 된장과 밀 된 장보다 아미노산성 질소 함량이 높았으며, 이는 원료인 콩의 함량이 높아서 아미노태 질소를 생산할 수 있는 급원이 많기 때문이라고 하였다. 본 연구에서도 간장제조에 사용한 메주 원료의 단백질 함량에 의해 그 분해산물인 아미노산성 질소 함량에 차이가 있는 것으로 판단되어진다.

볶음쌀 첨가 메주로 담근 간장의 유리아미노산 조성 비교 간장의 주요 성분인 유리아미노산은 식품의 풍미에 중요 한 역할을 하는 것으로 알려져 있다(Seo와 Lee, 1992). 볶음 쌀 첨가량을 달리하여 제조한 메주를 사용한 간장의 유리아미

Table 1. Total nitrogen and amino-type nitrogen contents of 'Ganjang' prepared from 'Meju' added with roasted rice

\begin{tabular}{ccc}
\hline $\begin{array}{c}\text { Roasted rice content } \\
(\%)\end{array}$ & $\begin{array}{c}\text { Total nitrogen } \\
\text { content }(\%)\end{array}$ & $\begin{array}{c}\text { Amino-type nitrogen } \\
\text { content }(\mathrm{mg} \%)\end{array}$ \\
\hline 0 & $1.51 \pm 0.00^{\mathrm{al})}$ & $836.64 \pm 2.43^{\mathrm{a}}$ \\
10 & $1.22 \pm 0.01^{\mathrm{b}}$ & $728.73 \pm 15.79^{\mathrm{b}}$ \\
30 & $1.13 \pm 0.00^{\mathrm{c}}$ & $651.18 \pm 2.92^{\mathrm{c}}$ \\
50 & $0.72 \pm 0.01^{\mathrm{d}}$ & $425.09 \pm 5.66^{\mathrm{d}}$ \\
\hline
\end{tabular}

${ }^{1)}$ Means \pm SD $(n=3)$ within each column followed by different letters are significantly different $(\mathrm{p}<0.05)$. 
노산 함량은 Table 2에 나타내었다. 유리아미노산 함량은 아 미노산성 질소 함량의 경향과 유사하게 나타남을 볼 수 있었 다. 유리아미노산은 무처리한 메주로 담근 간장에서 630.68 $\mathrm{mg} \%$ 로 높게 나타났으며, 볶음쌀 $30 \%$ 첨가한 메주로 담근 간장에서 $573.64 \mathrm{mg} \%$ 로 나타났다. 단맛을 내는 아미노산은 lysine, phenylalanine, serine, alanine, arginine, glycine, proline, threonine 등으로 알려져 있으며, 무처리 메주로 담 근 간장은 $232.44 \mathrm{mg} \%$, 볶음쌀 $30 \%$ 첨가한 메주로 담근 간 장은 $242.28 \mathrm{mg} \%$ 로 나타나 아미노산 구성에 단맛 아미노산 이 무처리에 비해 높음을 확인할 수 있었다. 특히 단맛 아미 노산 중 serin, threonine은 무처리보다 볶음쌀을 첨가한 간 장에서 높게 나타남을 볼 수 있었다. 쓴맛을 내는 아미노산인 arginine, histidine, isoleucine, leucine, methionine, valine 등 은 무처리 메주로 담근 간장에서 높게 나타남을 볼 수 있었 다. 감칠맛을 내는 glutamic acid 함량은 무처리 메주와 볶음 쌀을 첨가한 메주에서 그 함량이 유사함을 볼 수 있었다. 이
는 쌀을 알코올발효한 술덧에서도 glutamic acid가 총질소 화 합물에서 $10 \%$ 이상을 차지하는 것으로 보고(Choi 등, 2015) 되어 있으며, Choe 등(2002)의 쌀 품종별 아미노산 분석 결과 에서도 전체 아미노산 중 $19 \%$ 로 높은 함량을 나타내서 콩 대 신 쌀 첨가에 의해서도 glutamic acid가 높음을 확인할 수 있었 다. 따라서 볶음쌀을 $30 \%$ 첨가한 메주를 사용한 간장은 무처 리 메주 사용 간장에 비교해서 쓴맛을 내는 아미노산 함량이 낮아서 단맛 및 감칠맛을 더 낼 수 있을 것으로 기대된다.

\section{전자코 및 전자혀의 향미 패턴 비교}

간장의 품질 분석에서 환원당 함량 및 아미노산 조성이 우 수하게 나타난 볶음쌀을 $30 \%$ 첨가 간장과 무처리 원료콩으 로 사용한 부석태 간장과 장류 제조에 많이 사용하는 대원콩 으로 담근 간장과의 향미패턴 비교를 위해 전자코 및 전자혀 분석을 하였다. 전자코를 이용하여 간장의 휘발성분을 분석 한 후 이를 바탕으로 주성분 분석을 실시한 결과는 Fig. 4와

Table 2. Free amino acid composition of 'Ganjang' prepared from 'Meju' added with roasted rice

(Unit: $\mathrm{mg} \%$ )

\begin{tabular}{|c|c|c|c|c|}
\hline \multirow{2}{*}{ Free amino acids } & \multicolumn{4}{|c|}{ Roasted rice content $(\%)$} \\
\hline & 0 & 10 & 30 & 50 \\
\hline Histidine & $2.91 \pm 0.02^{1)}$ & $\mathrm{ND}^{2)}$ & ND & ND \\
\hline Serine & $7.04 \pm 0.09^{\mathrm{d}}$ & $11.40 \pm 0.10^{\mathrm{c}}$ & $23.77 \pm 0.17^{\mathrm{b}}$ & $24.93 \pm 0.02^{\mathrm{a}}$ \\
\hline Arginine & $40.04 \pm 0.12^{\mathrm{a}}$ & $36.83 \pm 0.12^{b}$ & $36.01 \pm 0.18^{\mathrm{c}}$ & $24.43 \pm 0.05^{\mathrm{d}}$ \\
\hline Glycine & $41.05 \pm 0.21^{\mathrm{a}}$ & $33.59 \pm 0.15^{\mathrm{b}}$ & $27.35 \pm 0.18^{\mathrm{c}}$ & $19.49 \pm 0.02^{\mathrm{d}}$ \\
\hline Aspatic acid & $16.58 \pm 0.42^{b}$ & $25.04 \pm 0.36^{\mathrm{a}}$ & $4.82 \pm 0.75^{\mathrm{d}}$ & $15.64 \pm 0.02^{\mathrm{c}}$ \\
\hline Glutamic acid & $77.87 \pm 0.13^{\mathrm{a}}$ & $76.73 \pm 1.13^{\mathrm{a}}$ & $77.06 \pm 1.65^{\mathrm{a}}$ & $63.45 \pm 0.05^{\mathrm{b}}$ \\
\hline Threonine & $2.01 \pm 0.01^{\mathrm{d}}$ & $21.48 \pm 0.19^{c}$ & $30.97 \pm 0.14^{\mathrm{a}}$ & $22.83 \pm 0.02^{\mathrm{b}}$ \\
\hline Alanine & $11.01 \pm 1.75^{\mathrm{a}}$ & $10.64 \pm 0.21^{b}$ & $10.61 \pm 0.05^{\mathrm{b}}$ & $3.83 \pm 0.01^{\mathrm{c}}$ \\
\hline Proline & $51.08 \pm 0.03^{\mathrm{a}}$ & $47.03 \pm 0.12^{b}$ & $39.04 \pm 0.18^{\mathrm{c}}$ & $26.75 \pm 0.02^{\mathrm{d}}$ \\
\hline Cystine & $1.59 \pm 0.03^{\mathrm{b}}$ & $1.58 \pm 0.02^{\mathrm{b}}$ & $1.63 \pm 0.00^{\mathrm{a}}$ & $1.57 \pm 0.00^{\mathrm{b}}$ \\
\hline Lysine & $55.72 \pm 0.06^{\mathrm{a}}$ & $42.72 \pm 0.29^{\mathrm{c}}$ & $52.75 \pm 0.15^{\mathrm{b}}$ & $28.66 \pm 0.02^{\mathrm{d}}$ \\
\hline Tyrosine & ND & $1.68 \pm 0.07^{\mathrm{b}}$ & ND & $25.54 \pm 0.03^{\mathrm{a}}$ \\
\hline Methionine & ND & $0.07 \pm 0.00^{\mathrm{c}}$ & $0.52 \pm 0.01^{\mathrm{a}}$ & $0.08 \pm 0.00^{\mathrm{b}}$ \\
\hline Valine & $63.26 \pm 0.12^{\mathrm{a}}$ & $62.43 \pm 0.31^{\mathrm{b}}$ & $57.84 \pm 0.32^{\mathrm{c}}$ & $39.23 \pm 0.06^{\mathrm{d}}$ \\
\hline Isoleucine & $76.48 \pm 0.02^{\mathrm{a}}$ & $71.83 \pm 0.38^{\mathrm{b}}$ & $56.82 \pm 0.30^{\mathrm{c}}$ & $36.72 \pm 0.01^{\mathrm{d}}$ \\
\hline Leucine & $108.48 \pm 0.04^{\mathrm{a}}$ & $73.76 \pm 0.55^{\mathrm{c}}$ & $93.62 \pm 0.45^{\mathrm{b}}$ & $55.64 \pm 0.03^{\mathrm{d}}$ \\
\hline Phenylalanine & $75.57 \pm 2.05^{\mathrm{a}}$ & $72.20 \pm 0.34^{\mathrm{b}}$ & $60.82 \pm 0.28^{\mathrm{c}}$ & $43.95 \pm 0.03^{\mathrm{d}}$ \\
\hline Total & $630.68 \pm 0.93^{\mathrm{a}}$ & $589.00 \pm 1.23^{b}$ & $573.64 \pm 1.43^{\mathrm{c}}$ & $432.74 \pm 0.34^{\mathrm{d}}$ \\
\hline
\end{tabular}

${ }^{1)}$ Means \pm SD ( $=3$ ) within each row followed by different letters are significantly different $(\mathrm{p}<0.05)$.

${ }^{2)}$ Not detected. 


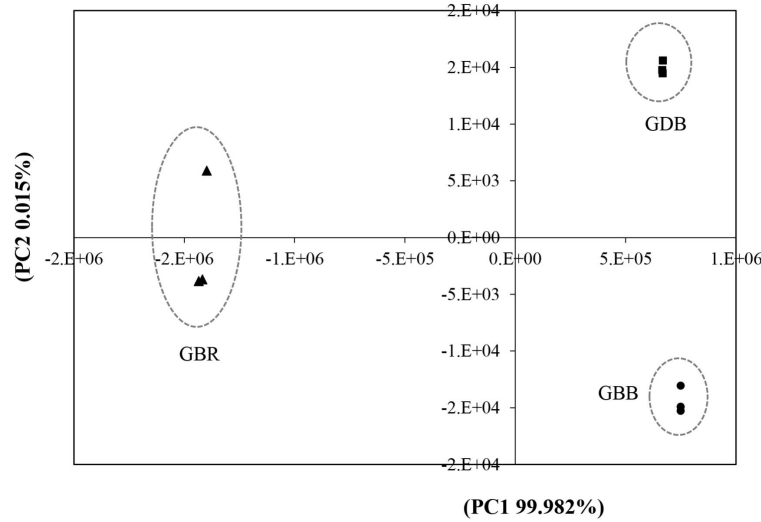

Fig. 4. Odor profiles based on PCA with E-nose measurements of 'Ganjang' prepared from 'Meju' with different materials.

GDB, 'Ganjang' using 'Meju' with 'Daewon' bean; GBB, 'Ganjang' using 'Meju' with 'Buseoktae'; GBR, 'Ganjang' using 'Meju' added with 'Buseoktae' and roasted rice 30\%.

같다. 제 1 주성분은 $99.982 \%$, 제 2 주성분은 $0.015 \%$ 의 점유율 을 나타내어 총 $99.997 \%$ 의 누적점유율을 나타내었다. 볶음 쌀을 첨가하지 않은 간장은 $\mathrm{PC} 1$ 을 기준으로 우측에 분리되 어 볶음쌀을 첨가한 간장과 뚜렷한 차이가 있어서 휘발성분 의 차이가 클 것으로 추측되었다. 대원콩 및 부석태 콩으로
제조된 간장에서도 $\mathrm{PC} 2$ 를 기준으로 차이가 있는 것으로 나타 나 원료콩에 따라서도 다소 차이가 있는 것으로 나타났다. 한 편, 전자코 분석에 의한 휘발성분을 Kovats retention indices 에 따라 AroChemBase library로 검색한 결과는 Table 3과 같 다. 즉, 볶음쌀을 첨가한 간장은 독특하게 ethyl acetate, tertbutyl acetate, pyrazine 등과 같은 과일향 및 볶음 향이 있는 것으로 나타났다. 전자혀 분석은 시판 증류주, 수삼의 원산지 판별 등의 연구에 적용되고 있다(Dong 등, 2017; Kim 등 2016). 간장의 전자혀 분석 결과는 Fig. $5 \mathrm{~A}$ 와 같다. 짠맛과 관련된 STS 센서는 차이가 없는 것으로 나타났으며, 감칠맛 과 관련한 UMS 센서는 볶음쌀을 첨가하지 않은 간장에서 높 게 나타난 반면에, 단맛을 나타내는 SWS 센서에서는 볶음쌀 을 첨가한 간장에서 높게 나타났다. 또한, 신맛 및 쓴맛을 나 타내는 SRS 센서 및 BRS 센서에서는 볶음쌀을 첨가한 간 장에서 낮게 나타남을 볼 수 있었다. 따라서 볶음쌀을 첨가 한 간장은 기존의 한식간장에 비해 단맛을 내며 신맛 및 쓴 맛은 감소됨을 전자혀를 통해 확인할 수 있었다. 전자혀 분 석결과, 주성분 분석에서 제 1 및 제 2 주성분의 기여율이 각각 $94.255 \%$ 및 $5.498 \%$ 를 나타내어 $99.753 \%$ 의 누적점유율을 나타내었다(Fig. 5B). $\mathrm{PCl}$ 을 기준으로 볶음쌀 $30 \%$ 를 첨가한 메주로 담근 간장은 우측, 부석태 콩 메주로 담근 간장은 중

Table 3. Volatile compounds identified by E-nose based on Kovats index on 'Ganjang' prepared from 'Meju' with different materials

\begin{tabular}{|c|c|c|c|c|}
\hline \multicolumn{2}{|c|}{ Retention time (sec) } & \multirow{2}{*}{$\begin{array}{l}\text { Possible matching } \\
\text { compounds }\end{array}$} & \multirow{2}{*}{ Odor properties } & \multirow{2}{*}{ Odor intensity $^{1)}$} \\
\hline DB5 & DB1701 & & & \\
\hline- & 34.17 & Isopropyl acetate & Fruity odor & $\mathrm{R}>\mathrm{B}>\mathrm{D}$ \\
\hline 40.44 & - & Propanoic acid & Pungent & $\mathrm{R}$ \\
\hline 22.02 & - & 1-Propanol & Mild, alcohol-like & $\mathrm{R}>\mathrm{D}>\mathrm{B}$ \\
\hline 26.73 & - & Ethyl acetate & Sweet smell & $\mathrm{R}$ \\
\hline 36.11 & - & tert-Butyl acetate & Fruity & $\mathrm{R}$ \\
\hline- & 24.33 & 2-Methyl-2-propanol & Camphorous & $\mathrm{R}>\mathrm{D}$ \\
\hline- & 23.52 & 2-Methylpropanal & Wet cereal or straw & $\mathrm{R}>\mathrm{D}>\mathrm{B}$ \\
\hline- & 44.49 & Pyrazine & Roasted products & $\mathrm{R}$ \\
\hline- & 38.66 & Propyl acetate & Mild, fruity & $\mathrm{R}>\mathrm{B}>\mathrm{D}$ \\
\hline- & 37.59 & Ethyl propanoate & Pineapple-like odor & $\mathrm{R}>\mathrm{B}>\mathrm{D}$ \\
\hline- & 29.71 & Butanal & Pungent, aldehyde odor & $\mathrm{R}>\mathrm{B}$ \\
\hline- & 21.61 & Dimethyl sulfide & Cabbage, sulfurous & $\mathrm{R}>\mathrm{B}>\mathrm{D}$ \\
\hline 27.86 & - & Acetic acid & Pungent/vinegar & $\mathrm{R}>\mathrm{B}$ \\
\hline 56.00 & - & Dibutyl ether & Fruity & $\mathrm{B}>\mathrm{R}>\mathrm{D}$ \\
\hline
\end{tabular}

${ }^{15} \mathrm{D}$, 'Ganjang' using 'Meju' with 'Daewon' bean; B, 'Ganjang' using 'Meju' with 'Buseoktae'; R, 'Ganjang' using 'Meju' added with 'Buseoktae' and roasted rice $30 \%$. 
(A)

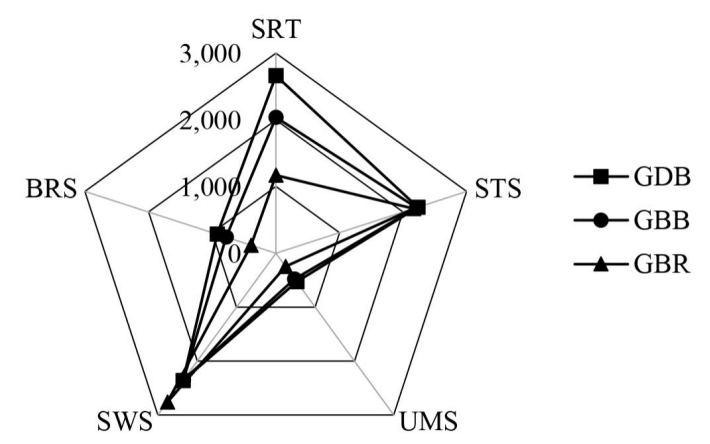

(B)

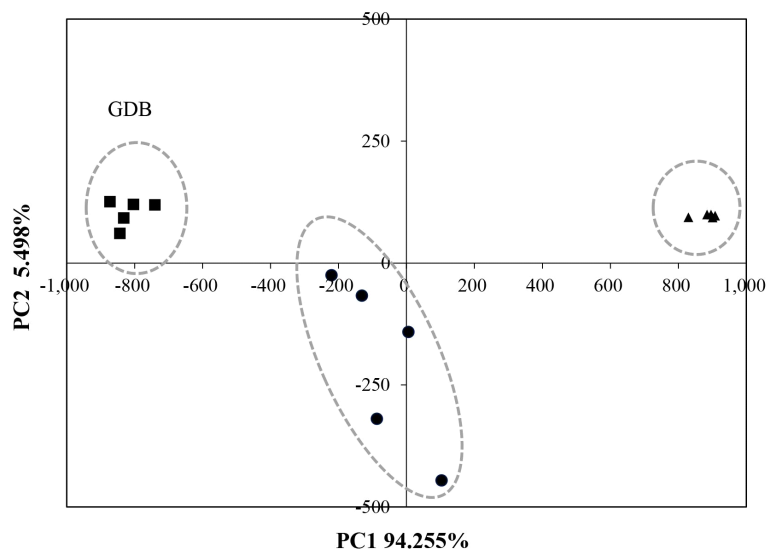

Fig. 5. Intensity comparison of 5 E-tongue sensors of 'Ganjang' prepared from 'Meju' under different materials (A) and taste profile based on PCA (B).

BRS, bitterness; SWS, sweetness; UMS, umami; STS, saltness; SRS, sourness; GDB, 'Ganjang' using 'Meju' with 'Daewon' bean; GBB, 'Ganjang' using 'Meju' with 'Buseoktae'; GBR, 'Ganjang' using 'Meju' added with 'Buseoktae' and roasted rice 30\%.

앙, 대원콩 메주로 담근 간장은 좌측에 나타나 맛에 있어서 차이가 있음을 볼 수 있었다. Jo 등(2016)은 전자코 분석으로 한국, 중국, 일본, 미국산 시판 사과식초에 존재하는 휘발성 화합물들에 대한 구별이 가능함을 보여주었고, Kim 등 (2008)은 전자코 분석을 통해 원산지에 따른 포도주의 휘발 성분의 변화를 구분할 수 있었으며, Rudnitskaya 등(2002)은 전자코와 전자혀를 이용하여 오렌지 주스 차이 분석에 응용 하였다. 본 연구에서는 전자코 및 전자혀 분석을 통해 메주에 따른 간장의 냄새와 맛의 차이가 남을 확인할 수 있었으며, 볶음쌀을 첨가한 메주를 사용한 간장에서 과일 향 및 볶음 향이 나며 단맛이 더 강함을 확인할 수 있었다.

\section{요 약}

본 연구는 기존의 전통적인 한식간장의 풍미 개선을 위해 볶음쌀을 첨가 $(0,10,30,50 \%)$ 한 메주 사용에 따른 간장의 품질특성을 조사하고, 기존의 한식간장과의 차별성을 분석하 고자 하였다. 그 결과, 볶음쌀을 첨가한 메주로 담근 간장의 총질소 및 아미노산성 질소 함량은 볶음쌀의 첨가량이 증가 할수록 감소되어지는 것으로 나타났다. 환원당 함량은 볶음 쌀을 $30 \%$ 첨가한 메주를 사용한 간장에서 높게 나타났다. 간 장의 유리아미노산을 분석한 결과, 볶음쌀을 첨가함에 따라 간장 제조 시 쓴맛을 내는 아미노산은 감소하며, 단맛을 내는 아미노산 중 serine, threonine 함량이 높게 나타났으며, 감칠 맛을 내는 glutamic acid 함량은 유사한 것으로 나타났다. 또 한 전자코 및 전자혀 분석으로 볶음쌀을 첨가한 메주를 사용 한 간장과 기존의 간장과 차이가 있음을 확인할 수 있었다. 전자코 분석시 차이 원인으로 볶음쌀을 첨가한 간장에서 ethyl acetate, tert-butyl acetate의 과일 향, pyrazine의 볶음 향이 있는 것으로 나타났으며, 전자혀 분석 결과, 단맛을 내 는 SWS 센서의 값이 높은 것으로 나타났다. 따라서 본 연구 를 통하여 기존 전통적인 간장 제조 시 단맛, 과일 향 및 볶음 향을 더하는 풍미개선 방법으로 볶음쌀의 활용 가능성을 확 인하였다.

\section{감사의 글}

본 논문은 농촌진흥청 지역특화작목기술개발과제(과제번 호: PJ013601022020 발효공정 개선을 통한 간장 품질 고급 화) 지원에 의해 이루어진 것임.

\section{Conflict of interests}

The authors declare no potential conflict of interest.

\section{ORCID}

Sung Ran Yoon https://orcid.org/0000-0001-5890-9071

\section{References}

Chang M, Chang HC. Characteristics of bacterial-Koji and Doenjang (soybean paste) made by using Bacillus subtilis DJ1. Kor J Microbiol Biotechnol, 35, 325-333 (2007)

Choe JS, Ahn HH, Nam HJ. Comparison of nutritional com- 
position in Korean rices. J Korean Soc Food Sci Nutr, 31, 885-892 (2002)

Choi C, Choi KS, Lee SH, Hong SP, Lee HD, Bae DK. Characteristics and action pattern of $\alpha$-galactosidase from Scopulariopsis brevicaulis in Korean traditional Meju. Agric Chem Biotech, 41, 489-495 (1998)

Choi HS, Kim EG, Kang JE, Yeo SH, Jeong ST, Kim CW. Effect of organic acids addition to fermentation on the brewing characteristics of Soju distilled from rice. Korean J Food Sci Technol, 47, 579-585 (2015)

Choi KS, Rhee HS. Characteristics of Doenjang made from different material and ratio of Koji. Korean J Soc Food Sci, 10, 39-44 (1994)

Choi SY, Sung NJ, Kim HJ. Physicochemical analysis and sensory evaluation of fermented soy sauce from Gorosoe (Acer mono Max.) and Kojesu (Brtula costata T.) saps. Korean J Food Nutr, 19, 318-326 (2006)

Choi UK, Park JH. Evaluation of taste in Kanjang made with barley bran using multiple regression analysis. Korean J Food Sci Technol, 36, 75-80 (2004)

Chung MJ, Jo JS, Kim HJ, Sung NJ. The components of the fermented soy sauce from Gorosoe and Bamboos sap. Korean J Food \& Nutr, 14, 167-174 (2001)

Dong HM, Moon JY, Lee SH. Discrimination of geographical origins of raw ginseng using the electronic tongue. Korean J Food Sci Technol, 49, 349-354 (2017)

Im JY, Kim SC, Kim S, Choi Y, Yang MR, Cho IH, Kim HR. Protein and amino-acid contents in Backtae, Seoritae, Huktae, and Seomoktae soybeans with different cooking methods. Korean J Food Cook Sci, 32, 67-574 (2016)

Jeon MS, Sohn KH, Chae SH, Park HK, Jeon HJ. Color characteristics of Korean traditional soy sauces prepared under different processing conditions. J Korean Soc Food Sci Nutr, 31, 32-38 (2002)

Jeong SJ, Shin MJ, Jeong SY, Yang HJ, Jeong DY. Characteristic analysis and production of short-ripened Korean traditional soy sauce added with rice bran. J Korean Soc Food Sci Nutr, 43, 550-556 (2014)

Jo YH, Gu SY, Chung NH, Gao Y, Kim HJ, Jeong MH, Jeong YJ, Kwon JH. Comparative analysis of sensory profiles of commercial cider vinegars from Korea, China, Japan, and US by SPME/GC-MS, E-nose, and E-tongue. Korean J Food Sci Technol, 48, 430-436 (2016)
Jung SW, Kim YS, Chung KS. Effects of preparation methods and aging temperatures on the properties of rice-Doenjang. Agric Chem Biotech, 38, 83-89 (1995)

Jung SW, Kwon DJ, Koo MS, Kim YS. Quality characteristics and acceptance for Doenjang prepared with rice. J Korean Agric Chem Sci, 37, 266-271 (1994)

Kaneko K, Tsuji K, Kim CH, Otoguro C, Sumino T, Aida K, Sahara K, Kaneda T. Contents and compositions of free sugars, organic acids, free amino acids and oligopeptides in soy sauce and soy paste produced in Korea and Japan. Nippon Shokuhin Kogyo Gakkaishi, 41, 148-156 (1994)

Kim JG. Changes of components affecting organoleptic quality during the ripening of traditional Korean soy bean paste: amino nitrogen, amino acids, and color. J Fd Hyg Safety, 19, 31-37 (2004)

Kim JS, Jung HY, Park EY, Noh BS. Flavor analysis of commercial Korean distilled spirits using an electronic nose and electronic tongue. Korean J Food Sci Technol, 48, 117-121 (2016)

Kim JY, Jang JS, Lee JW, Lee KT. Flavor pattern analysis of imported wines using electronic nose system. J East Asian Soc Dietary Life, 18, 14-21 (2008)

Kim ND. Trend of research papers on the soy sauce tastes in Japan. Food Industry and Nutrition, 12, 40-50 (2007)

Kyoun OY, Oh SH, Kim HJ, Lee JH, Kim HC, Yoon WK, Kim HM, Kim MR. Analyses of nutrients and antinutrients of rice cultivars. Korean J Food Cook Sci, 22, 949-956 (2006)

Lee EJ, Kwon OJ, Choi UK, Son DH, Kwon OJ, Lee SI, Yang SH, Im MH, Kim DG, Chung YG. Changes in taste components of Kanjang made with barley bran during fermentation. Korean J Food Sci Technol, 34, 85-90 (2002)

Lee GD, Yoon SR, Kim JO, Hur SS, Seo KI. Monitoring on the tea with steaming and drying process of germinated buckwheat. J Korean Soc Food Sci Nutr, 32, 212-217 (2004)

Lee JM, Ann SB, Kim YS, Hong YM, Yu JH. Studies on the substitution of raw materials for soy sauce. Part IV. Use of wheat gluten. Microbiol Biotechnol Lett, 2, 89-93 (1974)

Lee SY, Park NY, Kim JY, Choi HS. Quality characteristics of rice-doenjang during fermentation by differently 
shaped Meju and adding starter. Korean J Food Nutr, 25, 505-512 (2012)

Lee WJ, Cho DH. Microbiological studies of Korean native soy-sauce fermentation: A study on the microflora changes during Korean native soy-sauce fermentation. J Korean Agric Chem Soc, 14, 137-148 (1971)

Miller GL. Use of dinitrosalicylic acid reagent for determination of reducing sugar. Anal Chem, 31, 426-428 (1959)

Ministry of Food and Drug Safety. Korea Food Code. MFDS, Seoul, Korea, p 129-130 (2017)

Okamoto A, Hanagata H, Matsumoto E, Kawamura Y, Koizumi Y, Yanagida F. Angiotensin I converting enzyme inhibitory activities of various fermented foods. Biosci Biotech Biochem, 59, 1147-1149 (1995)

Park MZ, Kim ID, Kim SD. Effect of rice addition on enzyme activities of soybean Meju fermented by Monascus spp. Korean J Postharvest Sci Technol, 8, 405-411 (2001)

Rho JD, Choi SY, Lee SJ. Quality characteristics of soybean pastes (Doenjang) prepared using different types of microorganisms and mixing ratios. Korean $\mathrm{J}$ Food Cookery Sci, 24, 243-250 (2008)

Rudnitskaya A, Legin A, Makarychev-mikhailov S, Goryacheva O, Vlasov Y. Quality monitoring of fruit juices using an electronic tongue. Anal Sci, 17, 309-312
(2002)

Seo JS, Lee TS. Fee amino acids in traditional soy sauce prepared from Meju under different formations. J Korean Soc Food Cult, 7, 323-328 (1992)

Shi Y, Wang L, Fang Y, Wang H, Tao H, Pei F, Li P, Xu $\mathrm{B}, \mathrm{Hu} \mathrm{Q}$. A comprehensive analysis of aroma compounds and microstructure changes in brown rice during roasting process. LWT-Food Sci Technol, 98, 613-621 (2018)

Shin DH, Jeong DY. Korean traditional fermented soybean products: Jang. J Ethnic Foods, 2, 2-7 (2015)

Sun SK, Han EM, Lee TS, Lee MW. Brewing of acidhydrolyzed soy sauce with defatted soybeans and wheat flour Koji. Appl Biol Chem, 30, 147-152 (1987)

Yang HJ, Kim MJ, Hong SP. Anti-diabetic effect of Ganjang and Doenjang in different aging periods. Korean J Food Preserv, 26, 300-307 (2019)

Yoo SK, Kang SM, Noh YS. Quality properties on soy bean pastes made with microorganisms isolated from traditional soy bean pastes. Korean J Food Sci Technol, 32, 1266-1270 (2000)

Yu JH, Kim YS, Lee JM, Hong YM. Studies on the substitution of raw materials for soy sauce, Part I. Use of corn-gluten. Korean J Food Sci Technol, 4, 106-111 (1972) 